\title{
ADOPTION OF SRI PLANTING SYSTEM IN RANDUAGUNG VILLAGE, LUMAJANG REGENCY, EAST-JAVA, INDONESIA
}

\author{
Maulana Ainur Rohman ${ }^{1}$, Reza Safitri ${ }^{2}$ \\ ${ }^{1}$ Student in Study Program of Agribusiness, Faculty of Agriculture, University of Brawijaya \\ ${ }^{2}$ Lecturer in Department of Agricultural Socio-Economics, Faculty of Agriculture, University of \\ Brawijaya
}

*corresponding author: maulana664@gmail.com

\begin{abstract}
SRI (System of Rice Intensification) as planting system is technological innovation, which emphasizes on soil function as growth media and source of plant nutrition. Introduction process to the SRI technology in Randuagung Village, Lumajang Regency has been implemented for 5 years. However, farmers are still unwilling to implement the system. Therefore, it is necessary to identify the problems that cause slow SRI adoption of rice farmers. This research was qualitative descriptive and conducted on September to October 2016 to the "Tani Khisma Agung" Farmer Group. Sample determination method that used in this research was snowball sampling. It was started from 2 key informants and 18 informants. Data analysis used is interactive model developed by Miles, Huberman, and Saldana (2014), which consists of data condensation, data display, and conclusion drawing or verification. The research results showed that there were obstacles, causing slow adoption process of SRI planting system, which are related to labor system, water availability, less real proofs of the result or productivity, program continuity, late assistance, plant pest organism, and costs. Besides, there were other obstacles such as planning process with top-down system and group counseling method that less appropriate to the actual condition.
\end{abstract}

Keywords: Innovation adoption, SRI planting system, production technology,

\section{INTRODUCTION}

Rice is one of the most important agricultural commodities in Indonesia. Rice can be transform as food security in term of the enough availability to be accessed for everyone. Rice also can be seen as important economic production as livelihood of millions small-scale farmers. This commodity is also prominent due to the fact that it is consumed for about 350 million people of Indonesia. Rice is not only economic commodity but also as political stability as well as (Purnamaningsih, 2006).

In 1999, Indonesian government introduces a new method to be implemented in Indonesian farmers to deal with food security challenges. One of agricultural policy taken by Indonesian government was optimization of land and rice production using appropriate technology.

The new rice production technology then known as System of Rice Intensification (SRI). SRI is technological innovation which emphasizes on soil function as growth media and source of plant nutritions. This method is the implementation of irrigated rice production, which conducted on plants, soil, water, and nutrition management changes. The advantages of SRI planting system are maintained soil condition, larger plant's roots growth, and high productivity. Through this system, soil fertility can be regained to guarantee ecological cycle sustainably using soil microorganism to metabolite plant nutrition. Through this method, environmental sustainability can be preserved as well as human health level because there is no chemical compounds used for this agriculture system (Prayatna, 2007).

In the development of SRI, there are also many opportunities. It is in line with the development of actual implementation and farmer's interest including food, job, energy, cultivation, and environment. Rice cultivation using eco-friendly SRI approach and supporting local wisdom has many advantages to maintain food self-sufficiency in Indonesia. 
There are many internal and external factors encouraging the implementation of SRI nationally, especially in East Java. The followings are many driving factors about the importance of SRI method to be implemented. First, there is difficulty in increasing productivity and maintaining food selfsufficiency (rice). Second, ricefield agro-ecosystem is imbalance. Third, there is awareness to the quality of life and environment. Fourth, human resource empowerment model is strengthening by government program. Fifth, the improvement of product competitiveness due to rice produced by SRI program is free from synthetic chemical compounds.
The matter of facts that local government of Lumajang support this technology to be implemented in order to strengthen food security in the region. The local government creates socialization to the farmers and makes plot demonstration towards SRI planting system in Randuagung Village since 2010. Plot demonstration towards this SRI planting system in Randuagung Village showed that SRI planting system resulted final product potential with the average of 6-7 tons per hectare or about $20-40 \%$ greater than conventional rice cultivation which only results unhulled rice (gabah) about 4-5 tons per hectare.

Table 1. Adoption Level of SRI Planting System Technology Component

\begin{tabular}{|c|c|c|c|}
\hline No. & $\begin{array}{c}\text { Technology Component and } \\
\text { Adoption Category }\end{array}$ & Number(n) & Percentage $(\%)$ \\
\hline \multirow[t]{3}{*}{1.} & Seeds selection & & \\
\hline & Adoption & 3 & 16.6 \\
\hline & No Adoption & 15 & 83.4 \\
\hline \multirow[t]{3}{*}{2.} & Young seeds planting & & \\
\hline & Adoption & 2 & 11.1 \\
\hline & No Adoption & 16 & 88.9 \\
\hline \multirow[t]{3}{*}{3.} & Large plant spacing & & \\
\hline & Adoption & 18 & 100 \\
\hline & No Adoption & 0 & 0 \\
\hline \multirow[t]{3}{*}{4.} & Single planting (one place one seed) & & \\
\hline & Adoption & 0 & 0 \\
\hline & No Adoption & 18 & 100 \\
\hline \multirow[t]{3}{*}{5.} & Interval irrigation & & \\
\hline & Adoption & 3 & 16.6 \\
\hline & No Adoption & 15 & 83.4 \\
\hline \multirow[t]{3}{*}{6.} & Organic fertilizer & & \\
\hline & Adoption & 9 & 50 \\
\hline & No Adoption & 9 & 50 \\
\hline \multirow[t]{3}{*}{7.} & Botanical pesticides & & \\
\hline & Adoption & 2 & 11.1 \\
\hline & No Adoption & 16 & 88.9 \\
\hline
\end{tabular}

Based on table above, there is $16.6 \%$ farmers accept technology component of seeds selection and $83.4 \%$ reject the technology component. Farmers that accept technology component of young seeds planting is about $11.1 \%$ and $88.9 \%$ reject the technology component. For $16.6 \%$ farmers accept technology component of interval irrigation and $83.4 \%$ reject the technology component. The acceptance of technology component of organic fertilizer results in same percentage, where $50 \%$ farmers accept and $50 \%$ farmers reject it.

Component technology of large plant spacing has the best acceptance where $100 \%$ informant farmers have implemented the technology component. All informant farmers reject technology component of single planting with implementation percentage of $0 \%$. Thus, the farmers have problem implementing one place one seed due to the risk of the plan if there is some thing bad happened for the seed; then, there is nothing to be used for substituting it. That is the logical framework of farmers.

The researcher observed that although SRI planting system able to improve soil fertility through organic compound intake, intensify production facilities and water use, also increase farmer's income; however, the implementation of 
SRI planting system by farmers in Randuagung Village still very low.

The fact is that the farmers whoever have followed socialization of SRI planting system, do not apply SRI and comeback to use conventional method again. Eventhough, the conventional rice cultivation result in degrade environmental function and support capability.

That conventional system optimizes the use of outer input unwisely and inappropriate to the way how the local resources shoud be treated, especially in the use of synthetic agro-chemistry. Bad environmental support is going to be followed by the development of new plant pest organism that results in the decrease of agricultural production and has bad effect to the human's health.

By the explanation above, it can be concluded, temporary, that SRI planting system is better than conventional method. It is because the SRI planting system has longterm perspective of rice production that will preserve long-term profit of rice farming as well.

This research was conducted with the objectives as follow:

1) to describe the farmer group obstacles for the reason of not adopting rice cultivation using SRI planting system in Randuagung Village, Randuagung District, Lumajang Regency;

2) to describe counseling obstacles by counselors from UPT-BPP (Technical Implementation Unit - Agricultural Extension Institution) towards SRI planting system adoption in Randuagung Village, Randuagung District, Lumajang Regency.

\section{RESEARCH METHODS}

This research was qualitative descriptive research, which is intended to describe - systematic, factual, and accurate description - about an object or set of conditions in the present time as well as the relationship among the studied phenomena, which were farmer group obstacles to the SRI planting system adoption in Randuagung Village, Randuagung District, Lumajang Regency.

The selection of research location determined purposively with several considerations as following. First, it was due to SRI planting system has been socialized in that region. Secondly, ricefield type in Randuagung Village is ricefield with technical irrigation; thus, rice cultivation can be conducted throughout the year.

The researcher determined research subject purposively by using snowball sampling technique.
Subject criteria in this research as follow: 1) Member of "Khisma Agung" farmer group; 2) Active as farmer group member; 3) Have already presented in SRI planting system socialization and practices; 4) Willing to be research informant.

Snowball sampling type used by the researcher is exponential non-discriminative snowball sampling. The procedure is that the first subject will provide information about several references as subject candidates. The next, all references of new subject will be explored until the information obtained is adequate. In this research, it was obtained 18 informants from active member of "Khisma Agung" farmer group with criteria and information that needed in the research.

The key informant is also chosen to get information about related topics that studied by the researcher. In this research, the key informant was chief of UPT-BPP (Technical Implementation Unit - Agricultural Extension Institution) and Field Agricultural Extension Workers (PPL), who work in Randuagung Village.

Data collection method in this research was interview, observation, and documentation. Interview conducted in this research was semistructured interview by using more flexible guidance interview (adjusted with actual condition). The aims is to gain in-depth answers as what the researcher's expectated. The researcher also observed directly the activities of agricultural extension worker and farmer activities to the adoption process of SRI planting system. Documentation in this research is used to obtain information as much as possible from the research subject's life as written or exposed proofs in the research.

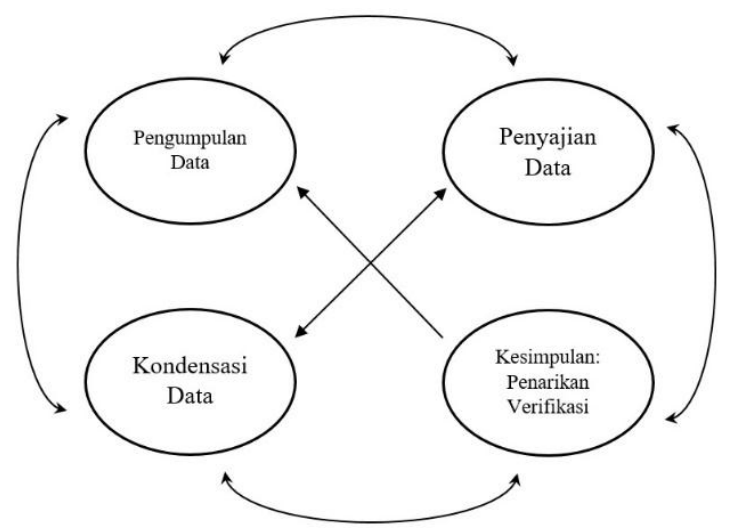

Figure 1. Components of Interactive Model Data Analysis

Data analysis that used in this research consisted of three simulatenous activities: data 
reduction, data display, and conclusion drawing or verification (Miles, Huberman, and Saldana, 2014).

One validity strategy used by the researcher in this study was data triangulation, in which it was triangulating different data sources and checking the proofs coming from the sources. The next is to develop justification of those facts gathered coherently. The more number of data sources or participant perspective will improve research validity (Creswell, 2010).

\section{RESULTS AND DISCUSSION Adoption of SRI Planting System Innovation}

1.) Labor

Majority of farmers in "Khisma Agung" farmer group use labours or workers for planting of rice crop to the harvest, where all the processes are conducted by labours. The fact observe is that the labors were unwilling to do their job if the rice cultivation used SRI planting system. It is because the implementation of SRI results in some differences comparing to the conventional planting. Therefore, the owners of the rice land, who implementing SRI, will have difficulty finding the labors.

To cope the problem above, many farmers have initiative to give additional wage or incentive to the labors in order to make them have willingness to work on the land with SRI planting system. However, it implies the higher costs that should be spent by landowner for rice production/cultivation.

\section{2.) Water availability}

Interval irrigation is type of irrigation used in rice cultivation with SRI planting system. Water availability becomes one of requirement in conducting interval irrigation. On dry season, that requirement becomes difficult to be met due to minimum water availability. Thus, water is difficult to reach ricefield area; even some farmers are willing to spend more costs by using diesel pump in order to irrigate their ricefield. This is realy the significant problem of implementing SRI in the location. The difficulty of implementation interval irrigation on dry season causes inappropriate time of water irrigation, thus it will result in negative effect to the plant growth.

\section{3.) Less real successful proofs}

The implementation of agricultural extension towards an innovation of plant cultivation needs a local experimentation regarding how the SRI should be implemented. This helps farmers in accelerating learning process and adoption to the innovation.

Majority farmers think that they have no real proofs about the result of rice cultivation using SRI planting system that been explained by Field Agricultural Extension Workers. Therefore, farmers are still in doubt of implement rice cultivation using SRI planting system on their own land.

The researcher observed that it was difficult to change farmer's mind to the new technology of rice production if they do not see the proofs from success farmers or local experimentation in implementing SRI. The farmers have no interest of adopting it if they do not see the proofs that SRI planting system is easier to be implemented and better technology in improving rice productivity and finally increasing farmers' income.

\section{4.) Program continuity}

Socialization of SRI, in fact, did not do optimally. There is no enough information socialized to the farmers and the learning process of SRI is stopped before the new technology is acquired properly to the farmers' mind. As the consequence, there will be inefficient adoption process for farmers due to discontinuous program.

\section{5.) Late of government input supports}

"Khisma Agung" farmer group members who implement SRI planting system program obtain a government support of organic fertilizers. These organic fertilizers are intended to improve ricefield fertility due to land damage as well as to shift farmer's behavior in applying chemical fertilizers. In the other words, this also will reduce the dependency of farmers to the chemical fertilizers and prefer to apply balance and more precise fertilizers utilization. Due to organic fertilizers have long term effect, then the Field Agricultural Extension Workers suggested to apply organic fertilizers during the land processing in order to make the organic fertilizers completely mixed with soil and accessible for plant growth in the right time.

The matter of facts however that the government supports of organic fertilizers mostly are getting late. For example, the fertilizers are just come after the plants already planted; thus, the farmers unable to implement fertilizer as what suggested by the direction of Field Agricultural Extension Workers.

Based on interview to the farmers, the researcher observed that farmers expect that the implementation of organic fertilizers is as fast as 
chemical fertilizer application. Therefore, the late application of organic fertilizer is also the problem due to the slow reaction of organic fertilizer to become available nutrients for the crop to be absorbed. For that reason, the extention program is very important to educate farmers the significant role of organic fertilizers in farming.

\section{6.) Plant Pest Organism}

The implementation of single planting to the ricefield has obstacle of golden apple snail pest. The attack of this pest still occurred although there are ditchs in order to make golden apple snails move to the ditchs and easy to be controlled. Besides, single planting system also causes young rice seeds will be attacked easily by golden apple snails. Therefore, the farmers have initiative to plant more than one seed per hole in order to anticipate pest attacks.

\section{7.) Costs}

The results from direct interview with farmers, the researcher assessed that the implementation of SRI planting system actually increases profit to the landowner. However, there will be additional cost of labours who are not familiar with SRI planting system; thus, they will need to finish their job slower or, in other words, it needs more labours.

Farmers also consider that cost of SRI planting system is higher than conventional planting system. Some farmers who have tried to implement SRI planting system found that there is unequal cost and rice production; then, they decided to go back to the conventional planting system.

SRI planting system uses interval irrigation as its technology component. It will causes faster growth of weeds, thus farmers should be weeding their ricefield more frequently. That affects to the labour cost eventually. These weeding activities should be conducted manually by labor and increasing the labor need for this acivities.

The additional costs are also necessary for organic fertlizer application. SRI planting system needs more amount of organic fertilizers; thus, it needs additional cost to the labours and the fertilizers as well. Finally, the farmers feel that the result of implementing SRI is not good enough compensating the difficulty in implementing it.

\section{Agricultural Extention in SRI Planting System \\ 1.) Program approach}

Program arranged by regional government (Ministry of Agriculture Lumajang Regency) is based on the target trying to be achieved by the government. Thus, the program using top-down approach, which is placing the farmers as object of the program or as passive agent and not based on what farmer's needs (self-determined).

The researcher viewed that this approach has several disadvantages, as follow:

a. First, the researcher found that extension program has supported the technical aspect but there is not enough understanding of how to cope the farmer's behavior in order for them adopting this new rice production technology appropriately.

b. Second, there is less incentive for agricultural extension workers for continuously developing understanding and changing behavior of farmers for adopting this new rice production technology. Thus, they cannot be optimally playing their role and empowering the farmer group. Extension workers are facing farmers as individual who does not easily believe with the new technology and as part of the society the farmer closely related to the local tradition that sometimes does not support the adoption process.

From the explanation above, the researcher assessed that it is necessary to change the agricultural development approach, from top-down to be bottom-up approach, where the farmers are the main actors of the program and government are played role as facilitator, supporting financial compensation, and source of innovation that should be implemented for increasing farmers' income.

Bottom-up approach, despite able to establish program as what farmer needs, also able to educate farmers to be more independent in the agricultural development program itself. That is also one of agricultural development's goal, which is to improve farmers' capacity in solving problems and increasing their welfare.

\section{2.) Agricultural Extension Method}

Method that used in the adoption of SRI planting system by UPT-BPP (Technical Implementation Unit - Agricultural Extension Institution) in Randuagung District was using group of farmers in the meeting, discussion, and local experimentation.

This method is design to create interaction among the farmers for exchange the experiments and strengthening the opportunity to adopt the new rice production, SRI. The problem is there are only few farmers who have already applied the SRI and some of them then rejected the SRI due to the less benefit obtained. The interaction among farmers who have failure experience in implementing SRI will reduce the belief of the other farmers for 
adopting SRI. It seems that nthe result of the farmers interaction is not as expected.

From this point, personal agricultural extension method or personal approach according to Kartasaputra (Setiana, 2005) is more effective to be applied in the counseling or extension because the target can directly be able to solve the problems by the specific guidance from extension workers. This method will quickly change farmer's behavior that previously failed to implement SRI planting system. Therefore, it is expected that farmers, that their problems been solved, can be role model in order to give positive effect in giving real proofs to the implementation of SRI planting system. Personal agricultural extension method, actually, is the most effective and intensive method than other methods. However, if the number of farmers are large enough, this method is rarely used because it relatively need more time of agricultural extension programs reaching the goal.

\section{CONCLUSION}

The reasons why farmers unwilling to implement SRI planting system are labor problem, water availability problem, less real proofs available, discontinuity of extension program, late input support by government, attacked pest problem, and increasing costs of production.

The success of agricultural extension workers in adoption of SRI is determine by many factors, such as the existed successful farmers in adopting SRI and the better communication between extension workers and farmers.

Communication between agricultural extension workers and farmers becomes one important part in the innovation technological transfer process. It needs enough time for agricultural extension workers to build farmer's awareness about the importance of innovation.
Moreover, the agricultural extension workers have to conduct monitoring and evaluation as an effort to cope with many problems existed in the field.

\section{SUGGESTION}

The government should assure that the input support comes in the right time. The organic fertilizers are needed before planting season; so, farmers can implement the new production technology as expected. For field agricultural extension workers, personal approach is better alternative to be applied to the farmers to strengthen the belief of farmers regarding SRI planting system. It is because personal approach will likely result a succesfull impelemntation of SRI than group approach.

\section{REFERENCE}

Creswell, J.W. 2010. Research Design Pendekatan Kualitatif, Kuantitatif, dan Mixed. Yogyakarta: pustaka pelajar.

Miles,M.B, Huberman,A.M, dan Saldana,J. 2014. Qualitative Data Analysis, A Methods Sourcebook Edition 3. USA: Sage Publication.

Prayatna, Soni. 2007. Pertanian Organik: Mengapa Harus SRI (System of Rice Intensification). Dinas Pertanian Kabupaten Tasikmalaya, Kerjasama dengan KTNA Kabupaten Tasikmalaya.

Purnamaningsih, R. 2006. Induksi Kalus dan Optimasi Regenerasi Empat Varietas Padi Melalui Kultur In Vitro.J. Agrobiogen. 2(2):74-80.

Setiana. L. 2005. Teknik Penyuluhan dan Pemberdayaan Masyarakat. Bogor: Ghalia Indonesia. 